\title{
化学と生物 文害館
}

植物二次代謝㢈物と農摹化学

\section{水谷純也 \\ 北海道大学名誉教授}

はじめに

もう半世紀以上も前になるが，筆者は当時の北海道大学農 学部農芸化学科農産製造学講座の大学院学生として, 故小幡 彌太郎先生の下で脱脂大豆を酸分解して調製したアミノ酸液 が出す硫化水素とジメチルスルフィド発生のしくみを調べて いた，小幡先生は，まだガスクロマトグラフや質量分析計な どの分析機器が登場する以前に，においの研究に取り組んで おられた先駆者のお一人である (写真 1 ). 先生はご自分が得 意とするハナリーゼ（鼻を使ってにおい成分を分析する）に よって, 魚のにおいやビールの日光臭などを嗅ぎ分け, 研究 室の学生たちにそれを実証するようにとテーマとして与え た。一方，与えられた学生のほうは，におい成分を単離同定 してにおいの本体を証明するため日夜悪戦苦闘していた。当 時は，同定するには，におい成分を結晶性誘導体に導き，標 品との混融試験や赤外線吸収スペクトルを比較するのがオー ソドックスなやり方であった.

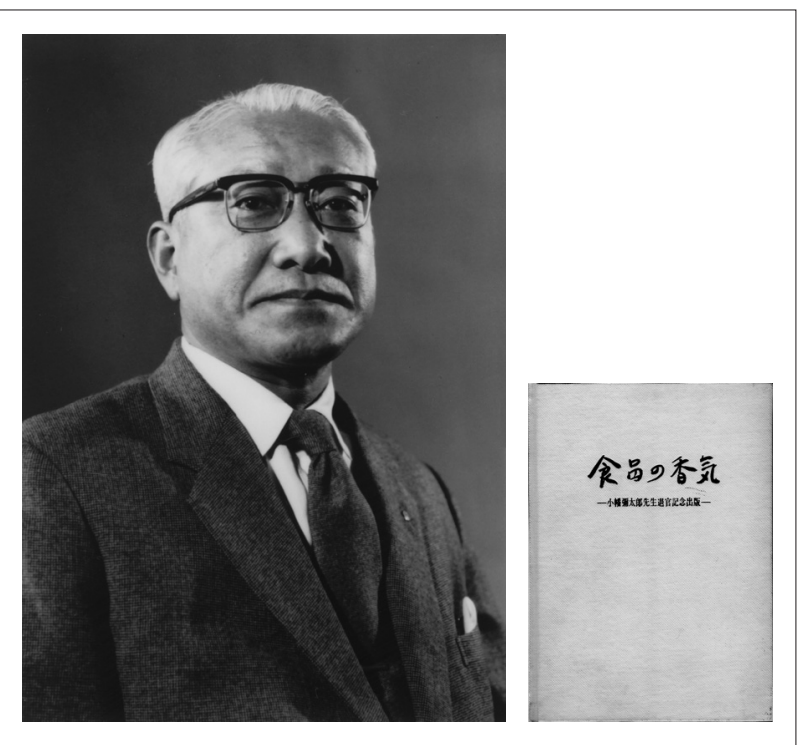

写真 1 - 小幡先生（左）と定年退官記念出版物 (1971)（右）
たまたま博士課程修了の年（1960 年），MIT（マサチュー セッツ工科大学) のフレーバー研究室に留学しておられたお 茶の水女子大学の山西貞先生（現名誉教授）が大学から直ち に帰国するようにと言われ，後任者の推薦を山西先生の出身 研究室である小幡先生のところへ依頼され，筆者に白羽の矢 が立った，当時，日本ではガスクロマトグラフが出はじめた ばかりで，筆者の研究室にはまだなかった．J.Agric. Food Chem. などにイチゴのフレーバー成分をガスクロマトグラ フを用いて分析している論文などが掲載されており，早くガ スクロマトグラフを使ってに拈いの研究をしてみたいと考え ていた矢先であった.

念願が叶って, MIT のフレーバー研究室に研究員 (ポスト ドクトラルフェロー）として留学することになった. フレー バー研究室は理学部の Department of Food Technology に 属しており, さすが MIT だけあって, 研究員の身分の筆者 でも 2 台のガスクロマトグラフを自由に使わせてもらえた. 研究室の主宰者は E. L. Wick 先生で, 山西先生から引き継 いだテーマは，牛肉を保蔵するために $\gamma$ 線を照射するといわ ゆる照射臭が発生して品質が落ちるが，その照射臭の本体を 突き止めるというものであった。当時は，ガスクロマトグラ フで分離してトラップに分取した成分を，赤外線吸収スペク トルを測定するなどして同定するというやり方で調べた，質 量分析計は登場したばかりであったが，将来有望な分析手段 になるであろうことが予想された。 また，核磁気共鳴も有機 化合物の構造解析に有用な手段になるであろうと期待された が，まだ実用段階にはなかった。

MIT で 3 年間近く過ごした後, 東京農工大学農学部農芸 化学科に採用され，6 年間ほど勤めた。恩師の小幡先生が新 設の農薬化学講座を担当されることになり，筆者は北大に戻 り，小幡先生の定年退官に伴い講座担任となった。 小幡先生 は「農薬をむやみに撒き散らしてはいけない，害虫の好きな においを用いワナを仕掛けて一網打尽，害虫だけを殺して農 作物を污染しないように誘引殽と併用すべきである」と言わ れていた，そこで筆者らは，北海道の主要作物夕マネギの重 要害虫である夕マネギバエの誘殺実験, マメ類などの発芽し たばかりの種子を食害する夕ネバエの誘引物質・産卵規制物 質の検索, ミツバチを農薬禍から護るための忌避物質の探索 
などを手掛けた。一方, ケミカルばかりでなく, たとえば放 射線による殺菌, 殺虫, 発芽抑制, 昆虫の不妊なども考える べきだという見地から，食品照射に関する国のプロジェクト にも参画した. タマネギの鱗茎に ${ }^{60} \mathrm{Co}$ からの $\gamma$ 線を照射す ると発芽が抑制される。しかしその際, フレーバーに影響を 与えないであろうか. その疑問は, 西村弘行博士（現東海大 学副学長) の含硫アミノ酸の放射線化学および光化学という 一連の基礎研究に発展した ${ }^{(1)}$.

\section{農薬の研究へ}

筆者らは, 広義の農薬の基礎研究として, 化学物質と生物 の相互作用を, 主として有機化学的手法により追究するとい う立場で, 種々の課題を取り上げてきた. ネギ属植物の香味 前駆体であるアリイン同族体のヒダントイン誘導体の抗菌活 性とその作用機構, キク科植物など植物界に広く分布する, ワモンゴキブリ雄に対する性刺激物質ゲルマクレン D, カイ コ幼虫腸内における病原細菌に対する防御機構, チャラン科 植物の化学成分, 高等植物 (ユーカリ属, ハッカ属, ショウ ガ科, アブラナ科など）のアレロパシー物質, ルーピン類の 抗菌性イソフラボン類とその微生物代謝, スゲ属植物の抗菌 成分, 地衣類の植物生理活性物質など, 多岐にわたっている. 一方で, 戦後の代表的な農薬であった DDT, BHC, パラチオ ン, 酢酸フェニル水銀など強力な有機合成農薬はすべて姿を 消し，これからの農薬はいかにあるべきかということが頭か ら離れなかった. 農薬の原点は何か? 植物は本来自分の身 を護るすべを有している. 夕バコ葉に含まれるニコチン，デ リス根に含まれるロテノン, ジョチュウギク成分のピレトリ ン, これらはいずれも植物二次代謝産物で防御物質である. アルカロイド, フェノール化合物, テルペノイドのような二 次代謝産物は植物が長い進化の過程で獲得したもので, 農薬 の原点といえるものである.

1960 年代に入ると, Butenandt ら (1962) によるカイコの 性フェロモン, ボンビコールの単離, 構造決定に始まる昆虫 の雌雄間の交信 (情報伝達) に関わる化学物質の探索, オ才 カバマダラの幼虫がガガイモ科植物トウワタから摂取した強 心配糖体（カルデノライド）を成虫になっても蓄えており， アオカケスに対する防御物質として利用しているという興味 ある事実 ${ }^{(2)}$ など, 化学物質が生物間相互作用に深く関わって いることが次第に明らかになって, 化学生態学と呼ばれる分 野の研究が盛んになってきた. その後の分析手法の進歩は, 特に HPLC, MS, NMR において目覚しいものがある. 生物 間相互作用に関わっている微量の化学物質を追跡することが 可能に，しかも容易になったのである.

筆者らの研究に欠くことのできない質量分析計や核磁気共 鳴装置は, 小幡先生や坂村貞雄先生 (現名誉教授) が中心と なって文部省科学研究費を申請し, それが通り, 1970 年ガス クロマトグラフ - 質量分析計 (GC-MS) の 1 号機（日立製 RMS4 型), 翌年核磁気共鳴装置の 1 号機（日立製 R-22 型,
$90 \mathrm{MHz},{ }^{1} \mathrm{H}$ のみ) を設置することができた.このような大型 機器の維持管理, 共同利用性を考慮し, 坂村先生の発案で農 学部に「GC-MS およびNMR 委員会」を設け, GC-MS と NMR は農学部共通の機器として, 学部内はもちろん, 広く 全学の共同利用に供されることになった，その後，科研費， 特別会計予算などで次々と新型の高性能 MS, NMR を購入 することができ，筆者らの研究推進に大いに役立った。

これら大型分析装置を用いての測定・保守管理には，当初 から渡部賢二技官の尽力によるところが大きかった。 その功 績が認められて渡部技官は 2000 年, 日本化学会から「難イオ ン化化合物の質量分析法の開発之応用」で化学技術有功賞を 受賞した. GC-MS・NMR 測定室ではその実績を評価され， 技術補佐員, 後に技官がもう 1 名補充され, 代々薬学部出身 者が分析業務を果たしてくれたが, 1989 年から農芸化学専攻 修士課程修了の福士江里修士（当時）が技官に採用され，現 在に至っている. 福士江里博士は 2004 年「天然有機化合物の 構造解析のための NMR 法の開発研究とその応用」で日本農 芸化学会から農芸化学奨励賞を受賞した。筆者がMIT に留 学したころ, 質量分析や核磁気共鳴が有機化合物の構造解析 に有望な手段であることは予想していたが，極微量でしかも 複雑な有機化合物の構造を解析できるようになろうとは驚く ばかりである。

そこで, 農薬の原点に帰り, 植物二次代謝産物を調べるこ とにした，学生を含む多くの共同研究者の協力により，筆者 らの仕事屯軌道に乗り始めた。 植物二次代謝産物に関する研 究は次第に認められ，筆者は 1988 年 10 月から 1993 年 9 月 までの 5 年間, 当時の新技術開発事業団（現科学技術振興機 構）から創造科学技術推進事業プログラムのひとつ, 植物情 報物質プロジェクトの総括責任者を引き受けることになっ た。この機会に広く野生植物にストレスを与えることによっ て生成する防御物質の探索を行なった。 北海道産野生植物約 250 種をスクリーニングにかけ，90 種以上の植物にストレス 誘導性抗菌性物質の存在を確認した。 本プロジェクトは植物 が本来備えている防御機構に着目して, そのしくみを化学的 側面から解明しようと試みたものである．植物は自分の意思 によって生活の場を変えることができない，それゆえ，与え られた環境に適応し, 防衛的・攻撃的システムを備えて身を 護り, 時には扶助的関係をもつこともある.このような防御 機構を主として天然物化学的・生態化学的アプローチによっ て調べた.

植物はさまざまな二次代謝産物をつくり出しており, その 中には植物を中心とした生物間相互作用に重要な役割を演じ ている植物情報物質（英語名 plant ecochemicals）が含まれ る. Plant ecochemicals という用語はプロジェクトが終了す るころには国際的にもかなり認知されるようになった ${ }^{(3 \sim 5)}$ （写真 2)，植物情報物質プロジェクトには海外も含め，延べ 19 名の若手研究者が参加してくれ, 得られた主要な成果は 『水谷植物情報物質プロジェクト終了シンポジウム記念論文 集』（平成 5 年 9 月 7 日，新技術事業団）として報告した. 

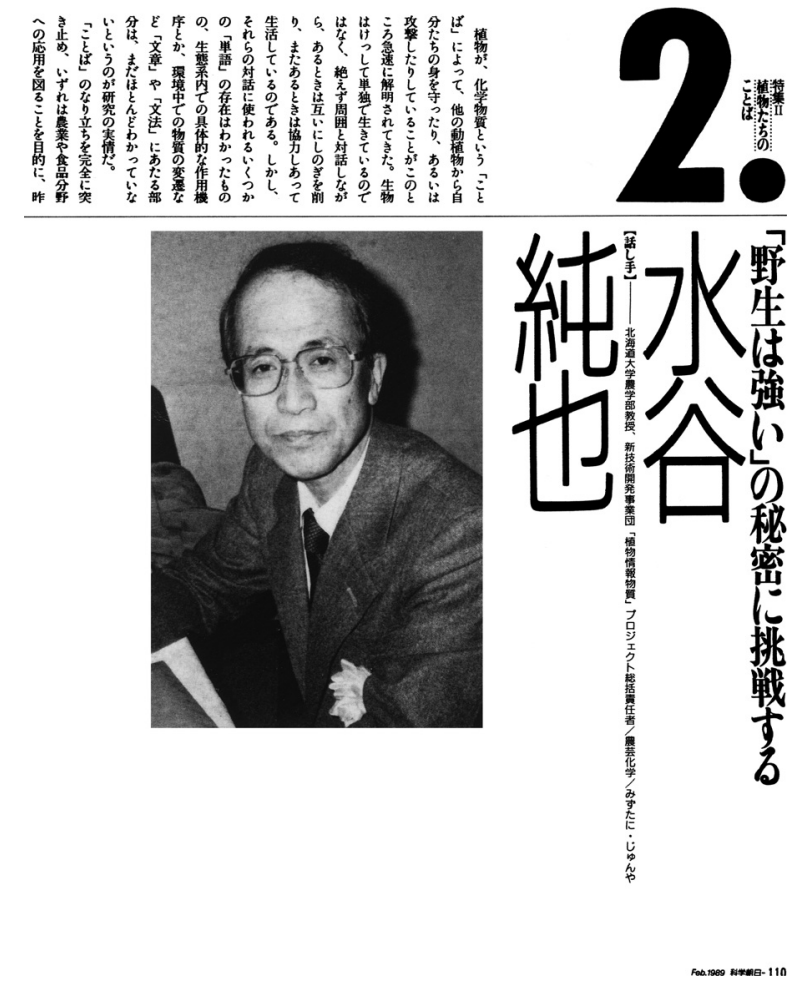

\section{農薬化学から生態化学へ}

1992 年, 北大農学部は改組が行なわれ，24 年間続いた農薬 化学講座は生態化学講座と名称を変更して新設の応用生命科 学科に移った。農薬というか作物保護の問題を, 自然生態系 を視野に入れて考えてゆこうというのである. 当時研究室に は講座創設時からのスタッフである田原哲士助教授（現名誉 教授), 1979 年農芸化学専攻修士課程修了の川端潤助手（現 大学院農学研究院食品科学分野教授）上筆者がおり, 田原博 士は後に日本農芸化学会功績賞の対象となったフラボノイド の生態生物化学に関する研究をはじめとする広範多岐にわた る学生の研究指導に当たり, 川端助手は「多量体構造を有す る植物由来抗菌性中分子精密構造解析」で日本農芸化学会奨 励賞を受賞し (1992 年), 同年, 旧農芸化学科を母体として再 編された生物機能化学科の新設食品機能化学講座助教授とし て転出した. 1989 年三井東圧化学株式会社から迎えた福士幸 治助手は, 後に「軸性キラル試薬を用いる NMR 構造解析法 の開発とその応用」で 1998 年日本農芸化学会奨励賞を受賞 した. 1995 年, 筆者は植物化学生態学研究室に移り, 生態化 学講座は田原教授, 橋床泰之助教授 (1996 年発令), 福士講師
写真 2 - 植物情報物質プロジェクトに関する記事

科学朝日, 49(2), p. 110 (1989)（左）と現代化学, 1993, No. 8, p. 30 (右)

\section{INTERVIEW}

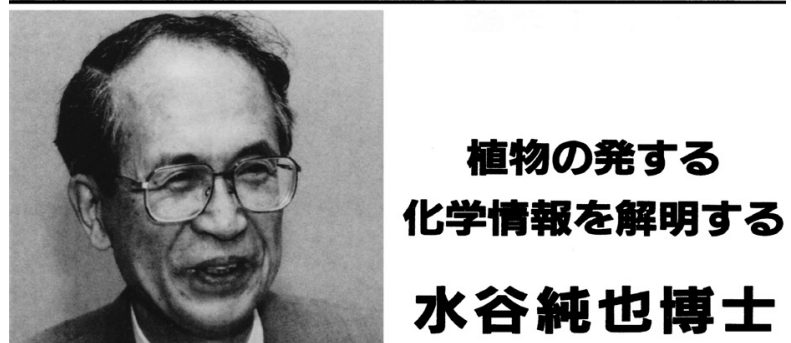
水谷純也博士

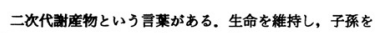

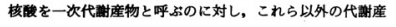

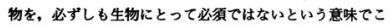
引呼占のてある。 しかし, 水谷料也博士は, そろ思っては

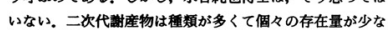

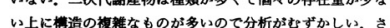

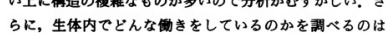

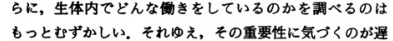

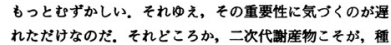
を特徴ら゙け，周囲の生物との間の情報のやりとりを担い,

水谷栖也（みずたに・じゅんや）

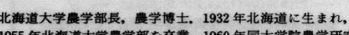

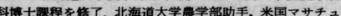

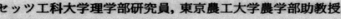

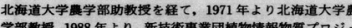

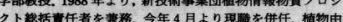
の生理活侍物置

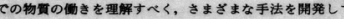

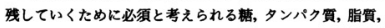

みみな租みて生命を守っているのだと考える。 ころした毁点に立つ水谷博士は, 野生植物の防御

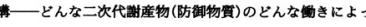

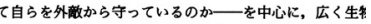
間相互作用全敉にも目を向け，研究を展開してきた，そ て，若いころに培った微量分析の失力と，研究者の柔敕

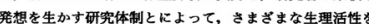
わ物質を次々に発見してきた。きれらの中には，植物。

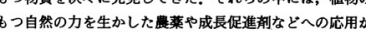
期待されるものるある.が、それ以上に, その一つ一つは 曼い進化の歷史を生き抜いてきた植物のたくましさのあた しとして興味溧し。

植物は化学物質で身を守る 一㥀物の防微機槽の研究に入られたきっっかけは?

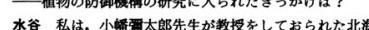

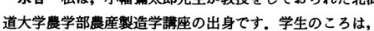

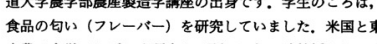
京農工大学てしばらく研究し,略和 44 年に助数授として小

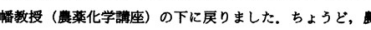
菜について, 残留毒性や生態系の破填などのマイナス面わ いわれ出したころてしたのて，誘引剂て害虫を集めてー゙
体制となる，橋床博士（現教授）は植物情報物質プロジェク トの研究員として, 八マナス葉の防御機構の解明やヤーコン 葉に着生する細菌がヤーコンの二次代謝産物である $p$-ヒド

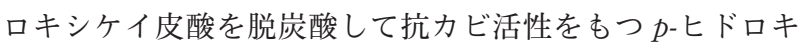
シスチレンに変換することを見いだすなどの成果を挙げ，後 に「二次代謝産物を介した高等植物之着生微生物の相互作用 研究」で 2003 年日本農芸化学会奨励賞を受賞した。

おわりに

筆者は 1996 年に定年退職し, 現在は生態化学研究室の行 く末を見守るだけの立場である。この原稿を引き受けるかど うかについては随分と迷ったが，編集委員長の村田幸作先生 のお言葉を都合良く解釈し，拙稿を作成した，紙面の都合で 割愛したところも多いが，長年にわたりご指導ご協力いただ いた皆様に深謝したい. に抢いの研究からスタートし，紆余 曲折を経て植物二次代謝産物，中でも植物を中心とした植物 情報物質 (plant ecochemicals) を取り扱うことになった。研 究を通じて親交のあったアレロパシーの研究で著名な C.-S. Tang ハワイ大学教授 (当時) む flavor chemist からこの分 
野に入ったと言っておられた。農薬化学講座の創設者であら れた天国の小幡先生は, 農薬化学から生態化学へのわれわれ の遍歴をどう見ておられるであろうか.

文献

1) H. Nishimura \& J. Mizutani :J. Org. Chem., 40, 1567 (1975).

2) J. B. Harborne: "Introduction to Ecological Biochemis- try, 4th ed.”, Academic Press, London, 1993, p. 90.

3) J. Mizutani: "Recent Advances in Allelopathy, Vol. 1. A Science for the Future", ed. by F. A. Macías et al., 1999, p. 149.

4) J. Mizutani : Crit. Rev. Plant Sci., 18, 653 (1999).

5) J. Mizutani: "Phytochemicals in Human Health Protection, Nutrition, and Plant Defense", ed. by J. T. Romeo, Kluwer Academic/PlenumPublishers, New York, 1999, p. 393.

\section{プロフィル}

廣田 佳久（Yoshihisa Hirota）＜略歴> 2008 年神戸薬科大学大学院修士課程修了 $/ 2008$ 年協和発酵工業 (株) (現 協和発酵 バイオ(株))研究員 $/ 2010$ 年神戸薬科大学 大学院博士後期課程入学, 現在にいたる <研究テーマと抱負 >ビタミン $\mathrm{K}$ を用い た創薬研究。一日一日着実に前進する<趣 味>サッカー観戦

廣田隆一 (Ryuichi Hirota) <略歴> 2002 年広島大学大学院先端物質科学研究 科博士課程後期修了/同年東和科学 (株) 博 士研究員 $/ 2005$ 年筑波大学大学院生命環 境科学研究科博士研究員 $/ 2007$ 年広島大 学大学院先端物質科学研究科助教, 現在に いたる<研究テーマと抱負>バクテリアの リン, シリコン代謝機構の解明と応用 $<$ 趣 味 >ベランダビオトープブくりに挑戦中

松浦 健二（Kenji Matsuura） <略歴> 1998 年京都大学農学部農林生物学科卒業 $/ 2000$ 年同大学大学院農学研究科修士課 程修了 $/ 2002$ 年同博士後期課程在学期間 短縮特例修了(農博) / 2004 年岡山大学大 学院自然科学研究科助手, 同助教を経て, 2008 年同大学大学院環境学研究科准教授, 現在にいたる。この間, 2002 年米国ハー バード大学進化生物学分野博士研究員, 2007 年北海道大学大学院農学院非常勤講 師(兼任), 2010 年京都大学大学院理学研究
科非常勤講師 (兼任) <研究テーマと抱負 $>$ 進化的合理性に基づく昆虫社会進化の網羅 的解明 $<$ 趣味 $>$ 儒教哲学

水谷 純也 (Junya Mizutani) <略歴> 1960 年北海道大学大学院農学研究科農芸 化学専攻博士後期課程修了/1963 年東京 農工大学農学部講師, 同助教授を経て, 1969 年北海道大学農学部助教授, 同教授を 経て，1996 年同大学定年退職.この間, 1960 年米国マサチューセッツ工科大学研 究員, 1988 93 年新技術事業団植物情報物 質プロジェクト総括責任者く研究テーマと 抱負 $>$ 地球環境く趣味>ウォーキング，プ 口野球観戦(テレビ観戦含む), 囲碁

水野 猛 (Takeshi Mizuno) <略歴> 1977 年名古屋大学大学院農学研究科博士 課程（後期課程）修了(農博)／同年三菱化 成生命科学研究所研究員 $/ 1984$ 年名古屋 大学農学部助教授 $/ 1989$ 年同教授, 現在に いたる.この間，1981～83 年米国二ュー ヨーク州立大学ストーニーブルック校生化 学部門留学 $<$ 研究テーマと抱負 $>$ 大腸菌, シアノバクテリア, 根粒菌, 酵母, 系状菌, ヒメッリガネゴケ，イネ，ミヤコグサ， シ ロイヌナズナなどの多様な生物を対象に, 一貫して二成分制御系の普遍性と多様性の 研究・教育を行なってきた。二成分制御系 の集大成を目指す<趣味 $>$ 野菜栽培歴 20
年

村 上洋 (Hiromi Murakami) <略 歴 $>1984$ 年甲南大学理学部生物学科卒業 $/ 1985$ 年大阪市立工業研究所生物化学課 研究員 $/ 1998$ 年同課研究主任 $/ 2007$ 年同 研究所生物 - 生活材料研究部研究副主幹 / 2008 年 (地独) 大阪市立工業研究所生物 生活材料研究部糖質工学研究室長, 現在に いたる. 1996 年理博 (大阪市立大学) <研究 テーマと抱負 >微生物および酵素を用いた 糖質の酸化に関する研究 $<$ 趣味 $>$ 家庭料理

森正 (Tadashi Mori) <略歴> 1994 年東京大学農学部農芸化学科卒業後, 田辺三菱製薬(株)を経て, 東北大学大学院 農学研究科博士課程後期 3 年修了 (農博) <研究テーマと抱負 $>$ 化合物之標的分子の 生物物理的相互作用 $<$ 趣味 $>$ テニス

柳原格（Itaru Yanagihara）<略歴> 平成 2 年山形大学医学部医学科卒業後, 大 阪大学医学部附属病院小児科 $/ 10$ 年同大 学微生物病研究所, 同研究所助手を経て, 14 年大阪府立母子保健総合医療センター 研究所部長, 現在にいたる. 平成 8 年医博 (大阪大学) <研究テーマと抱負 $>$ 周産期 小児期感染症の研究を通じて子供達の未来 を守る手伝いがしたいく趣味＞中高年のな んちゃって登山, アイスホッケー 